\title{
Determining if Lateral Imbalance Exists in First-order Branches Leading to a Potential Development of Torsional Stress
}

\author{
Gregory A. Dahle and Jason C. Grabosky
}

\begin{abstract}
The management of urban trees requires an ability to appraise the stability of trees to select where and when a maintenance task is required to increase the functionally useful period of the tree. Torsion is often ignored during static bending trials and the goal of this study was to determine if firstorder branches on open grown trees are laterally balanced. It is not known if lateral branch development leads to a parent branch that is evenly balanced. Second-order branch mass and center of gravity were measured and used to estimate the load acting on first-order branches. It appears that development can lead to imbalance in branches, because more than $60 \%$ of the first-order branches were imbalanced. Furthermore, $80 \%$ of the first-order branches in this specific study had more loading to the left side of the branch. Researchers should consider whether it is appropriate to ignore torsion when predicting how branches will behave during loading exercises. Additionally, the data suggests that it is possible to develop a strong predictive equation between branch length and the center of gravity $\left(r^{2}=95 \%\right)$ which, tied with predicted branch mass, could be useful when modeling self-loading and later balance in branches.

Key Words. Biomechanics; Branches; Center of Gravity; Mass; Stress, Tilia cordata; Torsion.
\end{abstract}

The management of urban and landscape trees requires an ability to appraise the stability of whole trees and tree parts for risks and value, and also to select where and when a maintenance task is required to increase the functionally useful service period of the tree or tree part. The normal stress formula (Formula 1) includes three load components: axial, bending, and shear stresses (Hibbeler 2005). This formula is utilized by engineers to determine the amount of stress at a given point on a structure whether under everyday loading or to estimate the failure load for the structure. Portions of this formula, axial $\left(\mathrm{P}_{\mathrm{x}} / \pi \mathrm{r}^{2}\right)$ and bending stress $\left(\mathrm{P}_{\mathrm{y}} \mathrm{LY} / 0.25\right.$ $\pi r^{4}$ ) have been applied to branch and tree pulling exercises (Lilly and Sydnor 1995; Dahle et al. 2006; Kane and Clouston 2008), yet the researchers did not include a shear stress $\left(\mathrm{Tr} / 1.57 \mathrm{r}^{4}\right)$ component. Many of the biomechanical models and studies in the arboricultural arena utilize static loading of trunks and branches. These studies have applied a bending load which often includes an axial load by default (Lilly and Sydnor 1995; Clair et al. 2003; Dahle et al. 2006; Kane 2007; Kane et al. 2008a; Kane and Clouston 2008; Smiley 2008). The researchers often stated that torsion was not applied since they were pulling downward and not twisting the branch, therefore shear stress was likely negligible. While failures can occur during static external loadings, such as with the accumulation of snow or ice, many failures occur during a combination of static and dynamic events that add wind gusts, hurricanes, or tornados (James et al. 2006). During such events, not only do branches sway and bend but they twist as the lateral branches intercept the wind (James 2003; James et al. 2006). The shear stress component may be of interest to help fully understand how branches behave and fail during dynamic loading events.

The normal stress equation for compression failures of a circular branch that is solid in cross section is as follows:

$$
\sigma=\frac{P_{x}}{\pi r^{2}}+\frac{P_{y}(L)}{0.25 \pi r^{3}}+\frac{T}{1.57 r^{3}}
$$

where $\mathrm{L}=$ failure moment $\operatorname{arm}, \mathrm{P}_{\mathrm{x}}=$ axial force, $\mathrm{P}_{\mathrm{y}}=$ bending force, $\mathrm{r}=$ radius at failure, $\sigma=$ normal stress, and $\mathrm{T} \stackrel{\mathrm{y}}{=}$ torque applied.

Whether or not shear stress is induced during a failure testing exercise of first-order branches (i.e., those arising from the central trunk), is a somewhat open question since they may develop in such a manner that they are relatively balanced in terms of torsion as a consequence of phyllotaxy (Harlow et al. 1991). As first-order branches grow over time, second-order (lateral) branches are produced, and many of the lateral branches grow for a period of time and then die while others continue to grow. This natural pattern of growth and death might lead to a branch that has a relatively even distribution of torsion applied from lateral branches growing on either side (left or right) of a vertical plane along the branch's longitudinal axis. Yet it is not known if lateral branch development (and subsequent death) leads to a parent branch that is evenly balanced, or if it becomes unbalanced in torsion due to a torque created by self-loading. Understanding whether a preload exists may be important to the arboricultural community. The removal of lateral branches during pruning could change the existing balance or unbalance, leading to a substantial shift in the self-loading of a branch, which therefore could increase the likelihood of branch failure during either external static or dynamic loading events.

The primary goal for this study was to determine if firstorder branches on open grown trees are laterally balanced. As shear strain, stress, and modulus of rigidity were not measured in this study, the torsional rigidity or overall stability of the branches cannot be addressed. This paper attempts to determine if more in-depth research is warranted on the torsional development and stability of branches. 
Additionally, knowing the center of gravity for a branch is important in determining how the load from a lateral branch acts upon the parent branch (see Formula 2), and thus is an important component of a branch's structural evaluation. Since the actual center of gravity cannot be known without destructive sampling, this point would need to be estimated. Research is sparse in non-destructive methods to predict the center of gravity. Researchers have utilized two-dimensional images to estimate center of pressure during dynamic loading (Kane and Smiley 2006; Smiley and Kane 2006; Kane et al. 2008b), but this is not directly related to center of gravity. This paper examines if it is possible to develop a predictive relationship to estimate the location of the center of gravity of branches. Finally, applying the load at the center of gravity may be important when considering dynamic loading over the whole tree or branch, such as during wind interception (Smiley and Kane 2006).

\section{METHODS}

Data was collected from August 24-26, 2010, at the Davey Research Farm, Portage County, Ohio, U.S., approximately $41^{\circ} 14^{\prime} 19^{\prime \prime} \mathrm{N}$ and $81^{\circ} 10^{\prime} 21^{\prime \prime} \mathrm{W}$. Soil was Ravenna silt loam. Three exterior growing first-order branches were selected from five Tilia cordata Mill. (littleleaf linden) trees, for a total of fifteen branches. Trees were between 38- and 46-years-old. The mean diameter at breast height (1.4 $\mathrm{m}$ above ground) for the five trees was $13.9 \mathrm{~cm} \pm 1.4 \mathrm{SD}$. Branches were selected to represent typical first-order branches in the lower half of the crown that likely acted as structural branches. Branches were removed from the tree and lowered to the ground to avoid loss of lateral branches. Overall branch length (using a string to follow the contour), angle of branch departure (A), diameter, and branch mass (M) were measured. Center of gravity (CG) was defined as the linear distance from the proximal base of the branch to the point at which the branch balanced evenly in one hand. All second order branches were removed from the first-order branch, until the first-order branch measured $2.54 \mathrm{~cm}$ in diameter. This location was chosen due to time constraints in the field and previous research has suggested that branch tips behave as a single branch (Dahle 2009). Secondary branch length, diameter, departure angle, point of attachment along first-order branch (POA), mass, and CG were recorded. Second-order branches were recorded as arising from either the left or right side of the first-order branch, looking towards the tip. Mass was measured within two hours of branch harvest with leaves in place using an Ohaus CD11 bench scale, measured to the nearest 10 g. Data was not recorded for branches weighing less than $10 \mathrm{~g}$.

Lateral balance $\left(B_{i}\right)$, an estimate for torsional moment applied by a second-order branch at the proximal end of a first-order branch, was calculated (Formula 2). Overall balance $\left(\mathrm{T}_{\mathrm{bal}}\right)$ along a first-order branch was calculated using Formula 3 and percent imbalance of the estimated torsional moments $\left(\mathrm{T}_{\mathrm{Pct}}\right)$ were calculated using Formula 4.

Secondary-order branch lateral load (B.) acting at the base of a first-order branch is determined with the following formula. Numeric subscripts denote a measurement obtained from 1) first-order branch or 2) second-order (lateral) branch.

$$
\mathrm{B}_{1}=\mathrm{G} \times \mathrm{M}_{2} \times \operatorname{Sin}(\mathrm{A}) \times \mathrm{CG}_{2} \times \mathrm{POA}_{1}
$$

where $\mathrm{A}=$ branch attachment angle, $\mathrm{B}=$ lateral branch force, $\mathrm{CG}=$ center of gravity $(\mathrm{cm}), \mathrm{G}=$ gravitational constant 6.674 $\times 10^{-11} \mathrm{~N}(\mathrm{~m} / \mathrm{kg})^{2}, \mathrm{M}=$ lateral branch mass $(\mathrm{kg})$, and POA = distance from lateral branch to first-order point of origin $(\mathrm{cm})$.

Overall balance $\left(\mathrm{T}_{\text {bal }}\right)$ of the first-order branch is as follows:

$$
T_{B a l}=\left|\sum B_{\text {Right }}-\sum B_{\text {Left }}\right|
$$

Percent imbalance of the first-order branch:

$$
T_{P c t}=T_{B a l} /\left(\sum B_{\text {Right }}+\sum B_{\text {Left }}\right)
$$

Data were analyzed in SAS 9.2 (SAS Institute), except standardized major axis (SMA) regression which used SMART 2.0 (Falster et al. 2006; Warton et al. 2006). Ordinary least squared (OLS) were run using Proc Reg, and Proc Univariate was used to verify normality of the variable and residuals. All variables were determined to be approximately normal, or adjusted using a $\log 10$ transformation. All statistics used $\alpha=0.05$.

\section{RESULTS AND DISCUSSION}

Mean branch length, diameter, slenderness, $\mathrm{BM}$, and $\mathrm{T}_{\mathrm{Pct}}$ for all first- and second-order branches are noted in Table 1. The aim was to select first-order branches that could be called structural branches, and the shortest first-order branch sampled was $370 \mathrm{~cm}$. Dahle and Grabosky (2010) suggested that $300 \mathrm{~cm}$ is the point at which branches growing on large shade trees, such as maple (Acer), transition from sun branches (solar collectors) to structural branches. Mean length for first-order branches in the current study was $477 \mathrm{~cm}$ (Table 1), and it appeared that these branches had transitioned to a structural role as nine of the first-order branches had second-order (laterals) that were longer than $300 \mathrm{~cm}$.

Table 1. Mean \pm SD for mean branch length, diameter, mass, and percent imbalance $\left(T_{\mathrm{Pct}}\right)$ for all first- and second-order Tilia cordata branches.

\begin{tabular}{lll}
\hline Variables & First-order branches & Second-order branches \\
\hline Length $(\mathrm{cm})$ & $476.9 \pm 60.3$ & $180.5 \pm 86.3$ \\
Diameter $(\mathrm{cm})$ & $6.1 \pm 1.1$ & $2.0 \pm 0.9$ \\
Mass $(\mathrm{Kg})$ & $8.7 \pm 4.3$ & $0.6 \pm 0.8$ \\
$\mathrm{~T}_{\text {Pct }}$ & $0.43 \pm 0.24$ & - \\
$\mathrm{N}$ & 15 & 110 \\
\hline
\end{tabular}

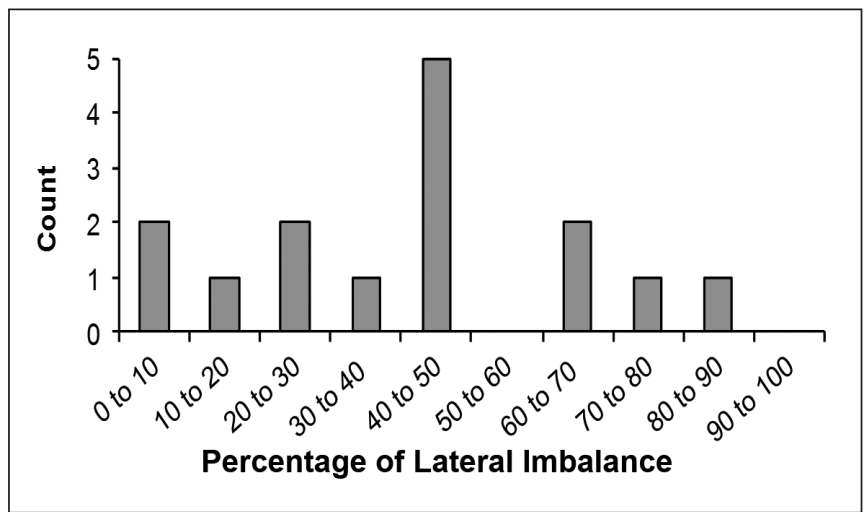

Figure 1.The number of first-order Tilia cordata branches and the percent imbalance of the estimated lateral moments for the first order branch. 
Overall, the first-order branches were not found to be balanced, as the mean percentage for $\mathrm{T}_{\mathrm{Pct}}$ was $43 \%$, with a range from $7 \%$ to $83 \%$. Since more than $60 \%$ percent of the first-order branches were imbalanced by $40 \%$ or more (Figure 1), it appears that the branches were likely preloaded with a torque. While this limited data set may not be representative for all tree branches it does suggest that normal development can lead to branches that are preloaded to one side, at least in branches with alternate attachment. The branches in this study were growing in all four cardinal compass directions (N, S, E, and W), and so researchers did not feel as though wind or light was a factor in overall branch imbalance. The only pruning on these trees was to raise the canopy for lawn mowing. The test branches did not appear to have any pruning scars and were located above the bottom of the canopy and thus were deemed unaffected by any canopy raising.

Interestingly, twelve of the fifteen branches had the greater $\mathrm{T}_{\mathrm{Pct}}$ to the left side of the branch, while three had greater moments on the right. Although it is unknown as to why this occurred it does not appear to be directly related to the solar position, as the branches were growing in all cardinal directions. This may be a function of growth in this particular species, yet more research is needed to determine if this apparent pattern is consistent across species or phyllotaxy (opposite versus alternate). OLS regression did not identify a relationship between $\mathrm{T}_{\mathrm{Pct}}$ and either the $\log$ branch length $\left(r^{2}=0.01, N=15\right)$ or the log branch diameter $\left(r^{2}=0.01, N=15\right)$. In total, the results suggest that the first-order branch allometry may not be directly affected by a lateral loading imbalance, although more research is needed to confirm this.

Modulus of rigidity, strain, or resulting shear stress were not measured in these branches, and therefore whether the apparent unbalance leads to the development of strains in the branch wood cannot be addressed. Branches most likely adapt to moderate strains during yearly radial growth, and therefore overall shear stress due to self-loading may not be a concern. Further research might be warranted to determine the levels of shear strain and stress during branch development and ascertain if selective removal during pruning operations leads to an increase in overall shear stress either during the short or long-term. The removal of a few branches on the less loaded side might further tip the imbalance resulting in a branch with a higher risk of failure during a loading event, such as wind, snow, or ice. Alternatively, reduction pruning could reverse the loading of an imbalanced branch, which could increase the risk of tissue delamination.

It must be pointed out that the loading imbalance identified in this study may only be valid for branches that have recently transitioned to structural branches. Imbalance may increase or possibly decrease as branch development continues. Additionally, the branches in this study displayed alternate branch attachment; it is not known if these findings will be similar to all alternate branching trees or to those with opposite branching.

It has been pointed out that trees build wood in a manner consistent with a need to protect against bending, which results in high flexural:torsional rigidity (Vogel 1995; Vogel 1996). Such adaptations have been invoked to suggest protection against failure in bending is more important than failure in torsion (Vogel 1995). Yet it appears that normally developed branches can be preloaded with a considerable torsional component. The inclusion of torsion may be important when investigating branch failure, especially in failures that occur during dynamic loading events. Researchers should consider including torsion in biomechanical models of branches and tree crowns before assuming an insignificant role in analysis.

The log of branch mass was significantly related to $\log$ branch length $\left(\log \mathrm{BM}=-6.48+2.69 \times \log\right.$ length, $\mathrm{r}^{2}=0.83$, $\mathrm{N}=124)$ and $\log$ branch diameter $\left(\mathrm{r}^{2}=0.95, \mathrm{~N}=124\right.$, Figure 2), both equations were determined using a SMA regression. This study confirms what previous research has shown in that branch diameter can be a good predictor of branch mass (Grabosky et al. 2007). If arborists are interested in estimating pruning dose, one method could be to use the branch diameter to estimate branch mass for a given species. Additionally, a significant SMA log-log relationship was identified between mass and center of gravity ( $\log$ mass $=-5.54+2.74 \log$ center of gravity, $\left.\mathrm{r}^{2}=0.83, \mathrm{~N}=124\right)$. As a relationship exists between mass and center of gravity, two important components of a branch's mechanics, future researchers may wish to investigate how the removal of a lateral branch or a branch subordination alters not only the overall mass of a given branch but the center of gravity and thus potentially the biomechanical makeup of the branch.

While no relationship was found between the log of a branch's center of gravity and $\mathrm{T}_{\mathrm{Pct}}\left(\mathrm{r}^{2}=0.015, \mathrm{~N}=15\right)$, significant OLS relationships were identified between a branch's center of gravity and the branch's diameter and length. The relationship with branch diameter was good $(\log C G=1.59+0.90 \times \log$ diameter, $r^{2}=0.76$ ), yet a stronger relationship was found with $\log$ branch length $\left(r^{2}=0.95\right.$, Figure 3$)$. This suggests that it is possible to estimate the center of gravity for a given branch with a high degree of confidence, which could be useful during failure testing exercises. Researchers would only need to remove a limited number of branches to derive a quick equation to provide an accurate estimate for the center of gravity and mass that could be used when modeling self-loading and lateral balance in branches.

It appears that development can lead to unbalanced branches. While it is not known if the unbalanced nature of branches will be found beyond $T$. cordata branches, this knowledge might be an important consideration during pruning operations. Research studies should consider whether it is appropriate to include torsion when utilizing the normal stress equation to predict how branches will behave during loading trials. Additionally, if research trials utilize a single attachment point, this data suggests that it is possible to develop a strong predictive equation for estimating where a branch's center of gravity lies.

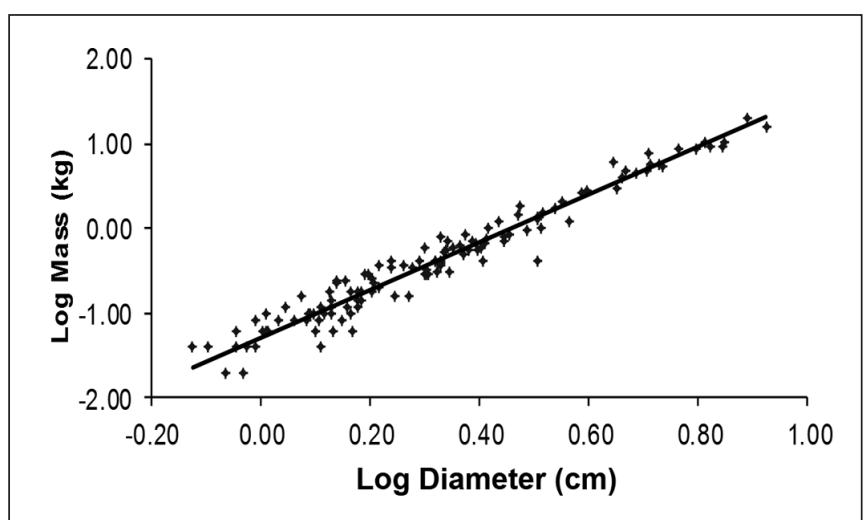

Figure 2. Log-log SMA relationship between branch mass and diameter for first and second order Tilia cordata branches. Log BM $=-1.29+2.82 \log$ diameter, $\mathrm{r}^{2}=0.95, \mathrm{~N}=124$. 


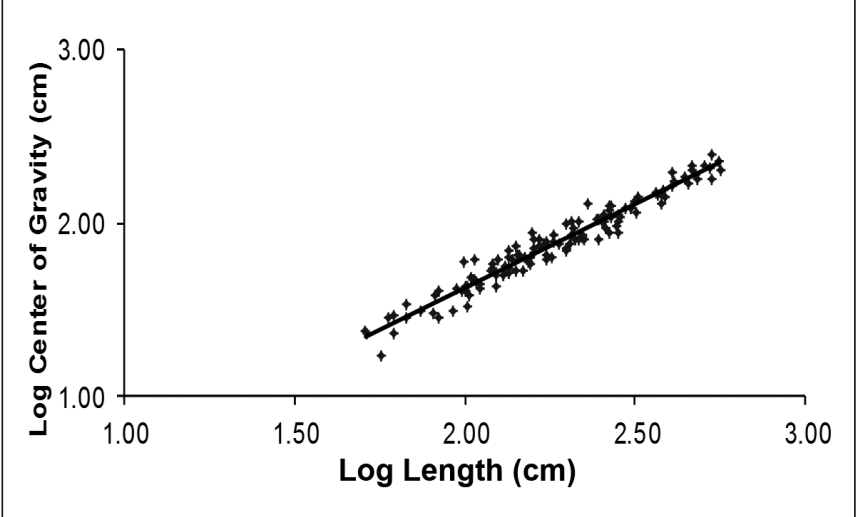

Figure 3. Log-log OLS relationship between length to branch center of gravity (CG) and branch length for first- and second-order Tilia cordata branches. $\log C G=-0.29+0.96$ log length, $r^{2}=0.95$, $\mathrm{N}=124$.

Acknowledgments. This research was funded by the TREEFund during the Tree Biomechanics Research Week and Symposium. We wish to thank the International Society of Arboriculture for organizing the research week, The Davey Tree Expert Company for access to the site and trees, and Tim Brown

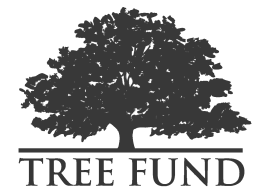

for assistance in climbing and data collecting.

\section{LITERATURE CITED}

Clair, B., M Fournier, M.F. Prevost, J. Beauchene, and S. Bardet. 2003. Biomechanics of bruttressed trees: Bending strains and stresses. American Journal of Botany 90:1349-1356.

Dahle, G.A. 2009. How the hydraulic and mechanical properties of wood influence branch form in Norway maple (Acer platanoides L.). Doctoral dissertation, Rutgers University, New Brunswick New Jersey, U.S. $156 \mathrm{p}$.

Dahle, G.A., and J.C. Grabosky. 2010. Allometric patterns in Acer platanoides (Aceraceae) branches. Trees: Structure and Function 24:321-326.

Dahle, G.A., H.A. Holt, W.R. Chaney, T.M. Whalen, D.L. Cassens, R. Gazo, and R.L. McKenzie. 2006. Branch strength loss implications for silver maple (Acer saccharinum) converted from round-over to V-trim. Arboriculture \& Urban Forestry 32:148-154.

Falster, D.S., D.I. Warton, I.J. Wright. 2006. SMATR: standardised major axis tests and routines, ver 2.0. <www.bio.mq.edu.au/ecology/ SMATR/>

Grabosky, J., E. Gilman, and C. Harchick. 2007. Use of branch crosssectional area for predicting pruning dose in young field-grown $Q u e r$ cus virginiana 'Cathedral' in Florida, US. Urban Forestry \& Urban Greening 6:159-167.
Harlow, W.M., W.S. Harrar, J.W. Hardin, and F.M. White. 1991. Textbook of dendrology. Covering the important forest trees of the United States and Canada 7th Edition. McGraw-Hill, Inc. New York, New York, U.S. $501 \mathrm{pp}$

Hibbeler, R.C., 2005. Mechanics of Material 6th Edition Pearson Prentice-Hall, Upper Saddle River, New Jersey, U.S. 873 pp.

James, K. 2003. Dynamic loading of trees. Journal of Arboriculture $29: 165-171$.

James, K.R., N. Haritos, and P.K. Ades. 2006. Mechanical stability of trees under dynamic loads. American Journal of Botany 93:15221530.

Kane, B. 2007. Branch strength of Bradford pear (Pyrus calleryana var. 'Bradford'). Arboriculture \& Urban Forestry 33:283-291.

Kane, B., and E.T Smiley. 2006. Drag coefficients and crown area estimation of red maple. Canadian Journal of Forestry Research 36:1951-1958.

Kane, B., R. Farrell, S.M. Zedaker, J.R. Loferski, and D.W. Smith. 2008a. Failure mode and prediction of the strength of branch attachments. Arboriculture \& Urban Forestry 34:308-316.

Kane, B., M. Pavlis, J.R. Harris, and J.R. Seiler. 2008b. Crown reconfiguration and trunk stress in deciduous trees. Canadian Journal of Forest Research 38:1275-1289

Kane, B., and P. Clouston. 2008. Tree pulling tests of large shade trees in the genus Acer. Arboriculture \& Urban Forestry 34:101-109.

Lilly, S., and T.D. Sydnor. 1995. Comparison of branch failure during static loading of silver and Norway maple. Journal of Arboriculture 21:302-305.

Smiley, E.T. 2008. Root pruning and stability of young willow oak. Arboriculture \& Urban Forestry 34:123-128.

Smiley E.T., and B. Kane. 2006. The effects of pruning on wind loading of Acer rubrum. Arboriculture \& Urban Forestry 32:33-40.

Vogel, S. 1995. Twist-to-bend ratios of woody structures. Journal of Experimental Botany 46:981-985.

Vogel, S. 1996. Blowing in the wind: Storm-resisting features of the design of trees. Journal of Arboriculture 22:92-98.

Warton, D.I., J.J. Wright, D.S. Falster, and M. Westoby. 2006. Bivariate linefitting methods for allometry. Biology Review 81:259-291.

Gregory A. Dahle

West Virginia University

Forestry \& Natural Resources

Morgantown, West Virginia 26506, U.S.

Jason C. Grabosky

Rutgers University

Ecology Evolution Nat Resources

14 College Farm Road

New Brunswick, New Jersey 08901, U.S. 
Zusammenfassung. Die Verwaltung von Straßenbäumen erfordert eine Fähigkeit, die Stabilität eines Baumes zu bewerten, um eine Auswahl zu treffen, wo und wann eine Erhaltungsmaßnahme erforderlich wird, um die funktional nützliche Standperiode eines Baumes zu verlängern. Torsion wird oft bei den statischen Untersuchungen zur Biegebelastung ignoriert und das Ziel dieser Studie lag in der Bestimmung, ob Äste der ersten Ordnung bei offen gewachsenen Bäumen lateral ausgewogen gewachsen sind. Es ist nicht bekannt, ob die Entwicklung lateraler Äste zu einem Starkast führt, welcher gleichmässig ausbalanciert ist. Die Masse der Äste zweiter Ordnung und deren Schwerpunkt wurden gemessen und die Ergebnisse verwendest, um die Last, die auf die Äste erster Ordnung wirken, abzuschätzen. Es kam vor, dass die Entwicklung die Äste aus dem Gleichgewicht brachte, weil mehr als 60\% der Äste erster Ordnung nicht ausbalanciert waren. Mehr noch, $80 \%$ der Äste erster Ordnung in dieser Studie hatten eine größere Last auf der linken Seite des Astes. Die Forscher sollten in Betracht ziehen, ob es angemessen ist die Torsion zu vernachlässigen, wenn Vorhersagen zum Biegeverhalten von Ästen unter Lasteintrag getroffen werden. Außerdem sagen diese Daten, dass es möglich ist, eine Gleichung zwischen Astlänge und Schwerpunkt $\left(r^{2}=95 \%\right)$ zu entwickeln, welche zusammen mit der vorhergesagten Astmasse nützlich sein kann bei der Abschätzung von Eigenlast und späterer Balance der Äste.

Resumen. La gestión del arbolado urbano requiere una habilidad para evaluar la estabilidad de los árboles para seleccionar dónde y cuándo una tarea de mantenimiento se requiere para aumentar el periodo funcionalmente útil del árbol. La torsión es a menudo ignorada durante los ensayos de flexión estáticos y el objetivo de este estudio es determinar si ramas de primer orden en los árboles crecidos abiertos lateralmente están equilibradas. No se sabe si el desarrollo de una rama lateral conduce a una rama padre que está equilibrada. La masa de una rama de segundo orden y el centro de gravedad fueron medidos y utilizados para calcular la carga que actúa en las ramas de primer orden. Parece que el desarrollo puede conducir al desequilibrio en las ramas, porque más del $60 \%$ de las ramas de primer orden estuvieron desequilibradas. Además, el $80 \%$ de las ramas de primer orden en este estudio específico se carga más a la izquierda de la rama. Los investigadores deben considerar si es apropiado omitir torsión cuando predicen cómo se comportarán ramas durante ejercicios de carga. Además, los datos sugieren que es posible desarrollar una ecuación predictiva fuerte entre la longitud de la rama y el centro de gravedad $\left(\mathrm{r}^{2}=95 \%\right)$ lo cual, atado con la masa de la rama prevista, podría ser útil cuando se modela la carga y posterior balance en las ramas. 